Bolibok P. (2016). An empirical evaluation of selected accounting-based value drivers in the Polish banking sector. Copernican Journal of Finance \& Accounting, 5(1), 25-37. http://dx.doi. org/10.12775/CJFA.2016.002

\author{
PIOTR BOLIBOK* \\ The John Paul II Catholic University of Lublin
}

\title{
AN EMPIRICAL EVALUATION OF SELECTED ACCOUNTING-BASED VALUE DRIVERS IN THE POLISH BANKING SECTOR
}

Keywords: banks, financial reporting, market value.

J E L Classification: G21, G32, M41.

\begin{abstract}
The paper aims at empirical evaluation of selected accounting-based value drivers in the Polish banking sector. Using the analyses of correlation and regression, the study investigates the associations between banks' charter values, proxied by Tobin's $Q$, and a set of explanatory variables including size, operating efficiency, profitability, net cash flow generation capacity, leverage, asset liquidity, and risk management efficiency, each proxied by a measure based on the data available in the annual financial reports of banks. The examined sample covered all domestically-based banks listed on the Warsaw Stock Exchange over the period 1997-2014. The empirical evidence indicates a statistically significant positive impact of operating efficiency, profitability and risk management efficiency on charter values. In turn, the influence of size and leverage, although also positive, appears to be so weak, that it becomes irrelevant when combined with other explanatory variables. Additionally, no statistically significant impact was found for net cash flow generation capacity nor asset liquidity. The above findings suggest that equity investors in the Polish banking sector perceive performance and risk management efficiency as the key value drivers, practically neglecting the issues related to banks' financial stability like the liquidity of assets or degree of leverage, thus presumably relying on the too-big-to-fail principle.
\end{abstract}

Date of submission: February 11, 2016; date of acceptance: May 11, 2016.

* Contact information: piotr.bolibok@kul.pl, Department of Banking and Finance, The John Paul II Catholic University of Lublin, Al. Racławickie 14, 20-950 Lublin, Poland, phone: +48814453433 . 


\section{INTRODUCTION}

Financial reports are one of the key sources of information used by investors in the developed capital markets. Given the time-consuming nature of recording the events in the accounting ledgers and of reporting process itself, financial statements are able to present only a historical view of the company. Despite this fact, the informational content of the reports is a foundation of all rational investment decisions based on corporate fundamental analysis and various security valuation techniques.

The impact of the announced accounting information on the decisions made by the investors and the market value of listed companies has been intensively examined in the relevant literature. The vast majority of studies in this area focuses, however, on non-financial enterprises while banks and other financial intermediaries are typically excluded from the examined samples.

Meanwhile, an ever increasing role of banks in the modern economies fully justifies turning some of the research attention to the value relevance of their accounting information. Although there is a considerable amount of international literature exploring this issue, the empirical evidence in the specific context of the Polish banking sector remains quite modest. Given the above, the present study aims at empirical evaluation of the key accounting-based value drivers of the listed banks in Poland, including size, operating efficiency, profitability, net cash flow generation capacity, leverage, asset liquidity, and risk management efficiency.

The remainder of the paper is composed of four sections. The first one provides a review of the relevant international and domestic literature on the accounting-based value drivers in the banking sector. The second briefly characterises the details of the methodological framework of the paper, including development of the research hypothesis and data selection procedures. The results of conducted empirical analyses are presented and discussed in the third section. The paper is closed with concluding remarks and suggestions on directions of future research.

\section{THE LITERATURE REVIEW}

Given the specificity of banking operations the market value of banks should reflect all major aspects of their business performance, including in particular capital adequacy and leverage, profitability, liquidity of assets, quality of 
risk management, and financial stability. Analyses of each of these areas for the purposes of security valuation are based primarily on the informational content of financial reports, thus creating direct links between various accounting data and banks' market value that have been explored in the relevant international literature for the last several decades.

The results of the studies investigating the impact of banks' equity capital on market value are ambiguous. According to Miller (1995) this capital should be value irrelevant due to the Modigliani-Miller leverage indifference theorem (1958). In turn, the arguments based on the agency models suggest that debt might be preferred by the equity investors as a source of funds due to the fact that it puts hard constraints on banks' management (see e.g. Hart and Moore 1995) while equity provides a protective cushion against erroneous business decisions. Another reason for a negative relationship between equity capital and value is the fact that holding equity due to regulatory capital requirements imposes a value-relevant cost on banks (see e.g. Allen, Carletti, Marquez 2011). Contrary to these viewpoints, however, Mehran and Thakor (2011) found that in the context of acquisitions bank value is positively correlated with bank capital.

Several studies investigated the value relevance of book values of equity and earnings in the banking sector. Both international (e.g. Abuzayed, Molyneux, Al-Fayoumi 2009; Agostino, Drago, Silipo 2011; Anandarajan, Francis, Hasan, John 2011) and domestic (Bolibok 2014) evidence indicates that book values and earnings are significantly, and positively, related to banks' market values.

Another strand of literature examines the impact of various bank-specific accounting items on banks' charter values, i.e. the present value of future rents or the value of bank's ability to continue its operations (usually proxied by Tobin's Q). The findings of De Nicoló (2000) indicate that although size of banks is generally negatively influencing their charter values, in the case of small banks this relationship becomes inversed. In turn, Gosh (2009) demonstrates that bank value is determined not only by the size but also by operating efficiency as he finds significant negative association between banks' charter values and both natural logarithm of total assets and C/I ratio. Fortin, Goldberd and Roth (2011) come to similar conclusions, finding a negative relationship between banks' price-to-book ratios (another proxy of banks' charter value) and size. Their results indicate a positive impact of ROE on charter values, however, it was statistically significant only in the period preceding the global eco- 
nomic crisis. In turn, equity capitalization (equity to total assets) seems to be negatively related to $\mathrm{P} / \mathrm{BV}$ in both the pre-crisis and crisis periods.

The results of a study by Jordan, Rice, Sanchez and Wort (2011) suggest that market-to-book ratios of banks are positively associated with x-efficiency (lower relative costs), net interest margins, non-interest income, and capital ratios while controlling for size and other bank attributes. Also Shamsuddin and Xiang (2012) demonstrate that technical, cost and profit efficiency have a positive effect on bank stock returns, which suggests that banks efficiency is directly aligned with their value to the shareholders.

Chiou, Porter and Sopranzetti (2014) decompose banks' ROA into five channels: interest income asset turnover, non-interest income asset turnover, interest contribution margin, non-interest contribution margin, and loan loss contribution and analyse their individual impacts on the relationship of market-to-book value, controlling for the impact of bank's size and leverage. Their results suggest that both interest and non-interest margins exert positive impact on banks' market values, while the influence of loan and lease losses is negative. Interestingly, according to Chiou et al. (2014) the value relevance of loan losses is much higher for larger banks, that seem to be punished more severely by the capital markets for the impairment of assets. Similarly, the impact of size on banks' market value appears to be statistically significant (negative) also for larger banks only.

Another set of studies examines the effect of impairment provisions on the market value of banks. Surprisingly, the results of these investigations are mixed as well. Although it would seem that such provisions should be valued negatively by the capital markets, some studies provide evidence of their positive impact. For instance Wahlen (1994) suggests that impairment provisions are in fact composed of discretionary and non-discretionary components. The discretionary component is subject to bank managers' manipulation and dependent on their motivation, whereas the non-discretionary one is an outcome of events related to default risk, lying beyond management's control. According to Wahlen (1994) bank managers use the discretionary component to convey positive signals about the future cash flow prospects which results in its positive relationship with the market value. Even though some studies provide support the signalling hypothesis (e.g. Beaver, Engel 1996), its foundations seem to be undermined by the findings of Ahmed, Takeda and Thomas (1999) as well as Lim, Walker and Lee (2013). Furthermore, the results of the study conducted in 
the context of the Polish banking sector by Bolibok (2015) indicate a negative impact of impairment provisions on the market value of banks.

The international evidence on the value of banks' cash flows is also ambiguous. The results of most studies suggest that specificity of banking operations is not fully captured by a standard cash flow statement framework which limits its informativeness for the equity investors (see e.g. Ryan, Tucker, Zarowin 2006; Gao 2015) According to Dimitropoulos, Asteriou and Koumanakos (2010) cash flows are outperformed by earnings in explaining variation in stock returns. Although, when earnings contain a high share of transitory components, cash flows tend to be more closely related to banks' market value.

Wang (2014) provides an evidence of a positive impact of operational diversification, capital adequacy ratio, and loan-to-capital ratio on banks' value. Moreover, unlike Gosh (2009), Fortin et al. (2011), and Chiou et al. (2014), he finds a positive association between banks' size and value. According to Wang (2014) the riskiness of banks' operations, (measured by the relations of derivative trading and non-performing loans to total assets) has negative impact on value.

\section{THE RESEARCH METHODOLOGY AND THE COURSE OF THE RESEARCH PROCESS}

Following the research framework commonly adopted in the relevant literature the present study attempts to evaluate empirically the impact of selected accounting-based value drivers on the charter value of listed banks in the Polish banking sector. Given the results of the prior studies, the following hypothesis was formulated:

Hypothesis 1.: Charter value of banks in the Polish banking sector is determined by their size, operating efficiency, profitability, net cash flow generation capacity, leverage, asset liquidity, and risk management efficiency.

danBank charter value is typically proxied by Tobin's $Q$ (relation of market value of bank's assets to their book value):

$$
C V \approx \text { Tobin's } Q=\frac{M V E+B V L}{B V A}
$$

where:*

- MVE - market value of equity, 
- $B V L$ - book value of liabilities (book value of assets - book value of equity),

- BVA - book value of assets.

The selected bank value drivers might also be proxied by specific accounting variables available in the banks' financial reports (Table 1.).

Table 1. Accounting-based proxies for the selected bank value drivers

\begin{tabular}{|l|l|}
\hline \hline \multicolumn{1}{|c|}{ Value driver } & \multicolumn{1}{c|}{ Accounting proxy } \\
\hline \hline Size & Natural logarithm of total assets \\
\hline Operating efficiency & C/I ratio \\
\hline Profitability & ROE \\
\hline Cash flow generation capacity & Net cash flows to total assets \\
\hline Leverage & Equity to total assets \\
\hline Liquidity & Liquid assets to total assets \\
\hline Risk management efficiency & Net impairment provisions to total assets \\
\hline
\end{tabular}

S o u r c e : own study.

In order to test the formulated hypothesis the analyses of correlation and multiple regression were employed. In the first stage of the research the Pearson linear correlation coefficients between the examined variables were estimated and tested for the statistical significance, whereas in the second stage the following linear regression model was estimated:

$$
\begin{aligned}
& \text { Tobin's } Q_{i t}=\alpha_{o}+\alpha_{1} \ln (T A)_{i t}+\alpha_{2} C /_{I_{i t}}+\alpha_{3} R O E_{i t}+\alpha_{4} N C F / T A_{i t}+\alpha_{5} E / T A_{i t} \\
& +\alpha_{6} L A / T A_{i t}+\alpha_{7} I P / T A_{i t}+\varepsilon_{t}
\end{aligned}
$$

where:

- Tobin's $Q_{i t}$ - Tobin's $Q$ of bank $i$ at the end of year $t$, as given by the formula (1),

- $\ln (T A)$ - natural logarithm of total assets of bank $i$ at the end of year $t$,

- $C / I_{i t}$ - operating expenses to interest, fee and provision income of bank $i$ in the year $t$,

- $R O E_{i t}$ - return on equity of bank $i$ in the year $t$, 
- NCF/TA $A_{i t}$ - net cash flow to total assets of bank $i$ in the year $t$,

- $E / T A_{i t}$ - equity to total assets of bank $i$ at the end of year $t$,

- $L A / T A_{i t}$ - liquid (current) assets to total assets of bank $i$ at the end of year $t$,

- IP/TA $A_{i t}$ - net impairment provisions to total assets of bank $i$ in the year $t$,

- $\alpha_{0}$ - intercept,

- $\alpha_{1} \alpha_{2}, \ldots \alpha_{7}$-regression coefficients,

- $\varepsilon_{t}$ - error term.

The estimate of the coefficient for $\mathrm{C} / \mathrm{I}$ ratio is expected to be negative while the one for ROE should be positive. As for the other explanatory variables, the mixed results of the prior studies make it much harder to predict the expected outcomes. Given the relatively small size of the banks examined in the present study and following the findings of De Nicoló (2000), one can expect a positive impact of size on the charter values Additionally, the fact that banks operate in a strictly regulated and supervised market setting, might lead the equity investors to focus mostly on banks' performance, relying on the too-big-to-fail principle, which might result in presumably negative associations between banks' charter values and both E/TA and LA/TA ratios. Finally, the ability to generate cash inflows should positively affect banks' charter values, while higher impairment provisions are likely to cause an exactly opposite effect. Therefore, the estimates of the coefficients $\alpha_{4}$ and $\alpha_{7}$ are expected to be positive and negative, respectively.

The data used in the analysis covered all domestically-based commercial banks listed on the Warsaw Stock Exchange over the period 1997-2014. Given the mergers and acquisitions within the sector, the final sample comprised of 18 banks. The data on annual financial statements and historical stock prices were collected from the Notoria Serwis SA database provided by ISI Emerging Markets (http://site.securities.com... 2015) and the Brokerage House of Bank Ochrony Srodowiska SA (http://bossa.pl... 2015), respectively. Given the fact that the study focuses on the bank-specific accounting variables the data from banks' separate financial statements were used. The combined data yielded the final pooled sample of 221 bank-year observations.

\section{THE OUTCOME OF THE RESEARCH PROCESS}

Table 2. presents the estimated values of the Pearson linear correlation coefficients between the examined variables in the pooled sample. 
Table 2. Correlation matrix of the examined variables (pooled sample)

\begin{tabular}{|l|c|c|c|c|c|c|c|c|}
\hline \hline Variable & Tobin's Q & In (TA) & C/I & ROE & NCF/TA & E/TA & LA/TA & IP/TA \\
\hline \hline Tobin's Q & 1.000 & $0.180^{* *}$ & $-0.407^{* *}$ & $0.211^{* *}$ & -0.087 & $-0.256^{* *}$ & 0.098 & $-0.436^{* *}$ \\
\hline In(TA) & & 1.000 & $-0.247^{* *}$ & -0.011 & -0.018 & $-0.289^{* *}$ & $-0.365^{* *}$ & $-0.180^{* *}$ \\
\hline C/I & & 1.000 & $-0.183^{* *}$ & -0.003 & $0.687^{* *}$ & -0.120 & $0.357^{* *}$ \\
\hline ROE & & & & 1.000 & -0.074 & $-0.210^{* *}$ & 0.085 & -0.068 \\
\hline NCF/TA & & & & & 1.000 & -0.063 & 0.066 & 0.049 \\
\hline E/TA & & & & & & 1.000 & -0.008 & $0.207^{* *}$ \\
\hline LA/TA & & & & & & & 1.000 & -0.035 \\
\hline IP/TA & & & & & & & & 1.000 \\
\hline \hline
\end{tabular}

** - correlation significant at the 0.01 level (2-tailed)

S o u r c e : own study.

Consistent with expectations, the conducted analysis revealed statistically significant, semi-strong, negative correlations between banks' charter values and both C/I and IP/TA ratios. A weaker, yet also statistically significant negative association, was found for E/TA ratio. As expected, estimated correlation coefficient between Tobin's $Q$ and both ROE and size turned out to be positive and significant, although quite low.

Correlation coefficients of the remaining variables (NCF/TA and LA/TA) with charter values, however, were estimated to be not significantly different than zero. Moreover, for each of these variables the sign of the coefficient turned out to be exactly opposite to the predicted one.

The above findings indicate that bank charter value in the Polish banking sector is driven by the operating efficiency, efficiency of risk management, leverage, profitability, and size, which partially supports the key hypothesis of the present study.

The correlations between the explanatory variables remained generally quite weak or statistically insignificant, except the positive associations between $\mathrm{C} / \mathrm{I}$ and $\mathrm{E} / \mathrm{TA}$ as well as $\mathrm{C} / \mathrm{I}$ and IP/TA and a negative one between $\ln (\mathrm{TA})$ and LA/TA, which suggest that less operationally efficient banks were typically operating under lower leverage and suffering from relatively higher impairment losses while larger banks tended to keep lower shares of liquid assets, as being able to run a borrowed-liquidity-type strategy. 
In the second stage of the research the Tobins' $Q$ of the banks was linearly regressed against the selected accounting-based variables (Table 3.).

Table 3. Estimations of the regression model (pooled sample)

\begin{tabular}{|c|c|c|c|c|c|c|}
\hline \multirow{2}{*}{ Variable/Statistic } & \multicolumn{2}{|c|}{ Regression coefficient } & \multirow{2}{*}{ t-statistic } & \multirow{2}{*}{$p$-value } & \multicolumn{2}{|c|}{ Collinearity Statistics } \\
\hline & Value & Std. Error & & & Tolerance & VIF \\
\hline Intercept & 0.809 & 0.173 & 4.680 & 0.000 & & \\
\hline $\ln (T A)$ & 0.014 & 0.009 & 1.539 & 0.125 & 0.753 & 1.329 \\
\hline $\mathrm{C} / \mathrm{I}$ & -0.057 & 0.018 & -3.142 & 0.002 & 0.462 & 2.164 \\
\hline ROE & 0.074 & 0.031 & 2.352 & 0.020 & 0.936 & 1.068 \\
\hline NCF/TA & -0.217 & 0.200 & -1.083 & 0.280 & 0.976 & 1.024 \\
\hline $\mathrm{E} / \mathrm{TA}$ & 0.192 & 0.332 & 0.579 & 0.563 & 0.496 & 2.017 \\
\hline LA/TA & 0.085 & 0.064 & 1.326 & 0.186 & 0.811 & 1.233 \\
\hline IP/TA & -2.128 & 0.418 & -5.091 & 0.000 & 0.856 & 1.169 \\
\hline$R^{2}$ & $29.6 \%$ & & & & & \\
\hline $\operatorname{adj} . R^{2}$ & $27.2 \%$ & & & & & \\
\hline F-statistic & 12.767 & & & 0.000 & & \\
\hline $\mathrm{N}$ & 221 & & & & & \\
\hline
\end{tabular}

S o u r c e : own study.

The estimated regression turned out to be statistically significant at the $1 \%$ level. Additionally, the values of variance inflation factors (VIF) do not suggest any serious problems with multicollinearity. The changes in the explanatory variables were, however, able to explain only about $30 \%$ of variation in banks' Tobin's Q.

The signs of the estimated regression coefficients were generally consistent with expectations, except the ones for NCF/TA, E/TA and LA/TA which, however, turned out to be statistically insignificant. The change in the sign of the regression coefficient for $\mathrm{E} / \mathrm{TA}$, compared to the corresponding correlation coefficient, is likely to be resultant from the interactions with other explanatory variables, in particular the aforementioned relatively strong positive correlation with $\mathrm{C} / \mathrm{I}$ ratio. 
Consistent with expectations, C/I and IP/TA ratios exerted statistically significant negative influence on the charter values of the examined banks. Interestingly, the changes in the latter ratio caused the highest responsiveness of Tobin's Q. Also the impact of ROE was positive and statistically significant, as presumed. Moreover, despite the aforementioned low correlation, the responsiveness of bank charter values to changes in ROE became in fact even stronger than that of $\mathrm{C} / \mathrm{I}$ ratio, when combined with other explanatory variables. In turn, the regression coefficient for the size proxy $(\ln (\mathrm{TA}))$, although positive, turned out to be statistically insignificant.

The results of the conducted analyses demonstrate that charter values of the examined banks were most sensitive to the changes in the relative scale of asset impairment. The efficiency of risk management appears therefore to be of crucial importance for equity investors in the Polish banking sector. As impairment provisions exerted strictly negative impact on charter values, it seems unlikely that they might be used for signaling purposes, which is in line with the findings of Ahmed et al. (1999), Lim et al. (2013), and Bolibok (2015).

Operating efficiency, proxied by $\mathrm{C} / \mathrm{I}$ ratio, seems to be an another important determinant of charter value in the investigated sample. The market clearly rewarded more cost-efficient banks, which is consistent with the findings of Gosh (2009), Jordan et al. (2011), as well as Shamsuddin and Xiang (2012).

The outcomes of both stages of the research process have also confirmed a statistically significant, positive impact of banks' profitability (measured with ROE) on their charter values. Even though a relatively low correlation of the aforementioned variables was quite surprising, the results of the regression analysis suggest that, when combined with other explanatory variables, ROE becomes even more value-relevant than C/I ratio. It is likely, however, that the value relevance of ROE might be in fact different in the periods preceding and succeeding the last global economic crisis, as suggested by Fortin et al. (2011), in particular due to considerably increased volatility of banks' net earnings resulting from significant fluctuations in impairment provisions after the beginning of the crisis.

The results of the investigation of the impact of banks' leverage on their charter values are ambiguous. On the one hand, a negative correlation between bank charter values and E/TA ratio indicates that the market rewards banks that take on higher leverage to improve their returns on equity, thus supporting the standpoints of Hart and Moore (1995) or Allen et al. (2011). On the oth- 
er hand, however, the extent of leverage becomes value-irrelevant when combined with other explanatory variables in the multiple regression model.

The findings regarding the impact of leverage on banks' charter values become particularly interesting in juxtaposition with an apparent value irrelevance of the liquidity of banks' assets (LA/TA ratio) which suggests that the equity investors in the Polish banking sector might not be particularly concerned about the issues related to banks' stability or solvency, assuming that regulatory supervision, deposit guarantees and other safety net solutions should enable the management of banks to concentrate their efforts on the maximization of profitability, even at the expense of higher risk exposure.

The examination of the impact of banks' size on their charter values produced mixed results as well. Even though the banks listed on the Warsaw Stock Exchange significantly differ among each other in size, in the international context they might be considered relatively small. In this light, an apparent positive correlation of banks' size on their charter values is consistent with the arguments of De Nicoló (2000) and Wang (2014). It seems that larger banks might be perceived by the investors as being more capable of exploiting the benefits arising from economies of scale and operational diversification. Moreover, given the aforementioned empirical evidence concerning the influence of leverage and asset liquidity, larger banks might be also regarded as being less exposed to the actual bankruptcy risk, following the "too-big-to-fail" principle. Similarly as in the case of leverage, the explanatory power of banks' size appears to be pre-emptied by the informational content of other predictors in the regression.

Finally, a negligible correlation between bank charter values and cash flow generation capacity (NCF/TA ratio) seems to be in line with the findings of Ryan et al. (2006) and Gao (2015) suggesting that a standard cash flow statement is of limited informativeness for the equity investors in the banking sector.

\section{CONCLUSIONS}

The results of the conducted research partially support the hypothesis of the present study. On the one hand, the empirical evidence indicates that the charter values of the banks listed on the Warsaw Stock Exchange are driven by operating efficiency, profitability and the efficiency of risk management. On the other hand, however, the evidence on the impact of banks' size and leverage is ambiguous, as even though they exhibit weak, yet statistically significant, correlations with banks' charter values, their explanatory power appears to be 
pre-emptied by the informational content of other predictors in the multiple regression model. Finally, the findings indicate that both cash flow generation capacity and the share of liquid assets appear to be of limited informativeness for equity investors, as they do not exert any statistically significant influence on banks' charter values.

The findings of the study suggest that equity investors in the Polish banking sector perceive performance and risk management efficiency as the key value drivers, practically neglecting the issues related to banks' financial stability like the liquidity of assets and degree of leverage, thus presumably relying on the too-big-to-fail principle. Given a relatively long time span covered by the present study, the further research in this field might try to investigate whether the aforementioned investors' attitude changes with the course of the business cycle and the overall level of risk aversion in the capital markets.

\section{REFERENCES}

Abuzayed, B., Molyneux, P., \& Al-Fayoumi, N. (2009). Market value, book value and earnings: is bank efficiency a missing link?. Managerial Finance, 35 (2), 156-179. http:// dx.doi.org/10.1108/03074350910923491.

Ahmed, A.S., Takeda C., \& Thomas, S. (1999). Bank loan loss provisions: A reexamination of capital management, earnings management and signaling effects. Journal of Accounting and Economics, 28 (1), 1-25. http://dx.doi.org/10.1016/S01654101(99)00017-8.

Agostino, M., Drago, D., \& Silipo, D.B. (2011). The value relevance of IFRS in the European banking industry. Review of Quantitative Finance and Accounting, 36 (3), 437-457. http://dx.doi.org/10.1007/s11156-010-0184-1.

Allen, F., Carletti, E., \& Marquez, R. (2011). Credit market competition and capital regulation. Review of Financial Studies, 24 (4), 983-1018. http://dx.doi.org/10.1093/ rfs/hhp089.

Anandarajan, A., Francis, B., Hasan, I., \& John, K. (2011). Value relevance of banks: global evidence. Review of Quantitative Finance and Accounting, 36, 33-55. http://dx.doi. org/10.1007/s11156-010-0170-7.

Beaver, W.H., \& Engel, E.E. (1996). Discretionary behavior with respect to allowances for loan losses and the behavior of security prices. Journal of Accounting and Economics, 22, 177-206. http://dx.doi.org/10.1016/S0165-4101(96)00428-4.

Bolibok, P. (2014). Application of the Ohlson model for testing the value relevance of accounting data in Polish banking sector. Zeszyty Naukowe Uniwersytetu Szczecińskiego, 802, Finanse, Rynki Finansowe, Ubezpieczenia, 65, 463-471.

Bolibok, P. (2015). Value relevance of impairment provisions in the Polish banking sector. Research Papers of Wroclaw University of Economics, 397, 58-67. http://dx.doi. org/10.15611/pn.2015.397.04. 
Chiou, W.J. P., Porter, R. L., \& Sopranzetti, B. J. (2014). Understanding the Channels of Bank Value Creation During Times of Crisis: Deconstructing ROA. Journal of Accounting and Finance, 14 (5), 11-23.

De Nicoló, G. (2000). Size, charter value and risk in banking: An international perspective. Board of Governors of the Federal Reserve System, 689, 1-42. http://dx.doi. org/10.2139/ssrn.255465.

Dimitropoulos, P.E., Asteriou, D., Koumanakos, E. (2010). The relevance of earnings and cash flows in a heavily regulated industry: Evidence from the Greek banking sector. Advances in Accounting, 26, 290-303. http://dx.doi.org/10.1016/j.adiac.2010.08.005.

Fortin, R., Goldberg, G. M., Roth, G. (2011). Bank charter value determinants during the 2008 financial crisis. Journal of Finance and Accountancy, 1-13.

Gao, Z., Li, W., O'Hanlon, J. (2015). The informativeness of US banks' statements of cash flows. Lancaster University Management School Working Paper, 1-53.

Gosh, S. (2009). Charter value and risk-taking: evidence from Indian banks. Journal of the Asia Pacific Economy, 14 (3), 270-286. http://dx.doi.org/10.1080/ 13547860902975606.

Hart, O., \& Moore, J. (1995). Debt and seniority: An analysis of the role of hard claims in constraining management. American Economic Review, 85, 567-585.

http://bossa.pl/notowania/metastock/ (accessed: 15.09.2015).

http://site.securities.com/cgi-bin/comp_profiles/94dec/PL/comp_profiles.html (accessed: 15.09 .2015$)$.

Jordan, D. J., Rice, D., Sanchez, J., \& Wort, D. (2011). Explaining bank market-to-book ratios: Evidence from 2006 to 2009. Journal of Banking and Finance, 35 (8), 2047-2055. http://dx.doi.org/10.1016/j.jbankfin.2011.01.017

Lim, C.Y., Walker, M., \& Lee, E. (2013). Are the loan loss and fair value components of bank income rationally priced? Research Collection School of Accountancy, Institutional Knowledge. Singapore Management University, 4, 1-51.

Mehran, H., \& Thakor, A. (2011). Bank capital and value in the cross-section. The Review of Financial Studies, 24 (4), 1019-1067. http://dx.doi.org/10.1093/rfs/hhq022.

Miller, M. H. (1995). Do the M\&M Propositions Apply to Banks? Journal of Banking and Finance, 19, 483-489. http://dx.doi.org/10.1016/0378-4266(94)00134-0.

Modigliani, F., \& Miller, M. H. (1958). The cost of capital, corporate finance and the theory of investment. American Economic Review, 48, 261-297.

Ryan, S., Tucker, J., \& Zarowin, P. (2006)., Classification and market pricing of the cash flows and accruals on trading positions. The Accounting Review, 81 (2), 443-472. http://dx.doi.org/10.2308/accr.2006.81.2.443.

Shamsuddin, A., \& Xiang, D. (2012). Does bank efficiency matter? Market value relevance of bank efficiency in Australia. Applied Economics, 44, 3563-3572. http:// dx.doi.org/10.1080/00036846.2011.577027.

Wahlen, J. M. (1994). The nature of information in commercial bank loan loss disclosures, The Accounting Review, vol. 69, no. 3, pp. 455-478.

Wang, M. S. (2014). Financial innovation, Basel Accord III, and bank value. Emerging Markets Finance \& Trade, 50 (2), 23-42. http://dx.doi.org/10.2753/REE1540496X5002S202. 